\title{
The effects of lead on photosynthetic performance of waxberry seedlings (Myrica rubra)
}

\author{
B. $\mathrm{HE}^{*,+}, \mathrm{M} . \mathrm{GU}^{*}, \mathrm{X} . \mathrm{WANG}^{*}$, and X. $\mathrm{HE}^{* *,+}$ \\ Guangxi Key Laboratory of Agri-environment and Agri-products Safety, College of Agriculture, \\ Guangxi University, Nanning, Guangxi 530005, China* \\ College of Agriculture, Guangxi University, Nanning, Guangxi 530005, China**
}

\begin{abstract}
The photosynthesis was investigated $30 \mathrm{~d}$ after $\mathrm{Pb}$ treatment in Myrica rubra seedlings. The $\mathrm{Pb}$ treatment resulted in significantly increased $\mathrm{Pb}$ concentrations in shoots. Low $\mathrm{Pb}$ concentration exposure $(\leq 2 \mathrm{mM})$ reduced the net photosynthetic rate $\left(P_{\mathrm{N}}\right)$, transpiration rate $(E)$, and stomatal conductance $\left(g_{\mathrm{s}}\right)$ without affecting the intercellular $\mathrm{CO}_{2}$ concentration $\left(C_{\mathrm{i}}\right)$, chlorophyll $(\mathrm{Chl})$ content, and $\mathrm{Chl}$ fluorescence parameters. At $10 \mathrm{~d}$ after severe $\mathrm{Pb}$ treatment $(\geq 4 \mathrm{mM})$, $P_{\mathrm{N}}$ was inhibited and accompanied by Chl damage, while at $30 \mathrm{~d}$, the inhibition of $P_{\mathrm{N}}$ was followed by an increase of $C_{\mathrm{i}}$ and a decrease of $g_{\mathrm{s}}, E, \mathrm{Chl}$ content, and Chl fluorescence parameters. $M$. rubra showed a promising prospect for use in the soil phytoremediation, when $\mathrm{Pb}$ concentration is low, but the remediation efficiency of $M$. rubra is limited if $\mathrm{Pb}$ exceeds $2 \mathrm{mM}$.
\end{abstract}

Additional key words: chlorophyll fluorescence; lead stress; photosynthesis.

\section{Introduction}

Lead $(\mathrm{Pb})$ is one of the most common heavy metal pollutants in the environment according to the United States Environmental Protection Agency (Watanabe, 1997). The Ministry of Land and Resources of China (MLRC) and the Ministry of Environmental Protection of China (MEPC) conducted a national soil pollution survey from 2005 to 2013 . The survey results show that nearly $1.5 \%$ of all survey points across mainland China were polluted by $\mathrm{Pb}$, and $1.1,0.2,0.1$, and $0.1 \%$ of these survey points were suffering minor, low, moderate, and serious $\mathrm{Pb}$ pollution, respectively (MLRC and MEPC 2014). Pb released from industrial units, metallurgical operations, and mining activities affects plant growth, directly or indirectly. $\mathrm{Pb}$ pollution influences morphological, physiological, and biochemical processes. It results in a decreased seed germination and plant growth as well as an increase in lipid peroxidation, oxidative stress, and DNA damage (Sharma and Dubey 2005, Sengar et al. 2008,
Gupta et al. 2009, Yadav 2010, Shahid et al. 2011). The $\mathrm{Pb}$-induced damages to photosynthesis may be caused by a reduction in photosynthetic pigments (Drazkiewicz 1994, Sharma and Dubey 2005, Hussain et al. 2006) and changes in the fine structure of chloroplasts (Fargašová 2001). This may also inhibit the photosynthetic electron transport system (Rashid et al. 1994), cause changes in ratios of unsaturated lipids, saturated lipids, and protein of chloroplast membranes (Stefanov et al. 1995, SkórzyńskaPolit and Baszyński 1997), and inhibit Calvin cycle enzymes (Parys et al. 1998).

In general, 5-7 years old trees can grow to heights of 5-15 m, with an annual biomass production of $150 \mathrm{tha}^{-1}$ (Caparròs et al. 2008). Recently, because of the large amount of biomass production, outstanding growth rate, and their high accumulation and tolerance to heavy metals, Paulownia tomentosa, Myrica rubra, and other tree species have been considered as effective plants for their

Received 22 October 2016, accepted 17 July 2017, published as online-first 12 April 2018.

${ }^{+}$Corresponding authors: e-mail: (B. He) hebing@gxu.edu.cn; (X. He) honest66222@163.com

Abbreviations: AOS - activated oxygen species, $C_{\mathrm{i}}$ - intercellular $\mathrm{CO}_{2}$ concentration; $\mathrm{Chl}$ - chlorophyll; $E$ - transpiration rate; $\mathrm{F}_{0}$ - minimal fluorescence of the dark-adapted state; $\Phi_{\mathrm{PSII}}-$ effective quantum yield of PSII photochemistry; $\mathrm{F}_{\mathrm{v}} / \mathrm{F}_{\mathrm{m}}-$ maximal quantum yield of PSII photochemistry; $g_{\mathrm{s}}$ - stomatal conductance; $P_{\mathrm{N}}-$ net photosynthetic rate; $\mathrm{q}_{\mathrm{N}}$ - nonphotochemical quenching coefficient; qP - photochemical quenching coefficient; WUE - water-use efficiency.

Acknowledgements: We would like to thank editors for editing and improving the language of the manuscript. We also thank Dr. Reza Hajimorad, University of Tennessee, Knoxville, USA, for linguistic assistance. This research was supported by the National Natural Science Foundations of China (Grant Nos. 30560007, 31060087, 31560122), and the "Soil Pollution and Ecological Remediation" Talent's Small Highland Project of Guangxi Province. 
use in phytoremediation (He et al. 2004, Doumett et al. 2008, Witters et al. 2009, Tzvetkova et al. 2015). The massive production of biomass in areas with a high $\mathrm{Pb}$ concentration allows $M$. rubra to remove significant amounts of $\mathrm{Pb}$ from polluted soils. Previously, we showed that $M$. rubra seedlings could grow normally in Hoagland solution with $1 \mathrm{mM} \mathrm{Pb}$ and accumulated $1,108 \mathrm{mg}(\mathrm{Pb}) \mathrm{kg}^{-1}$ in leaf tissue (He et al. 2004). Subsequently, studies have shown that $2 \mathrm{mM} \mathrm{Pb}$ could induce antioxidant defense mechanisms that could prevent oxidative damage and increase the soluble sugar content allowing $M$. rubra seedlings to minimize dehydration damage (He et al.

\section{Materials and methods}

Plant material, growth conditions and harvest: Selfrooted, one-year-old and uniform seedlings of $M$. rubra were collected from Dongkui bayberry farm in Nanning, Guangxi Province, China. Old leaves were removed to minimize transpiration and the seedlings were transferred into a greenhouse with a relative humidity of no more than $60 \%, 30 / 25^{\circ} \mathrm{C}$ day/night temperature, and PPFD of $150 \mu \mathrm{mol} \mathrm{m} \mathrm{m}^{-2} \mathrm{~s}^{-1}$. Each plant was cultivated in a plastic pot with $5 \mathrm{~L}$ of half-strength Hoagland nutrition solution (pH 5.4). The nutrition solution was aerated 20 min per hour, adjusted to $\mathrm{pH} 5.4$ with $0.1 \mathrm{mM} \mathrm{HCl}$ per day and renewed once per week. After one month, 40 seedlings were divided into four groups of ten and cultivated with nutrition solution supplemented with $0,2,4$, and $6 \mathrm{mM}$ $\mathrm{Pb}\left(\mathrm{NO}_{3}\right)_{2}$ (Sigma-Aldrich Biotechnology, St. Louis, MO, USA) for $30 \mathrm{~d}$, respectively. Tissue samples of stems and leaves were collected separately at 10 and $30 \mathrm{~d}$ after the beginning of $\mathrm{Pb}$ treatments. The leaves were divided into two parts, which were used for the analysis of chlorophyll (Chl) and $\mathrm{Pb}$ content, respectively.

Pb concentration: The stem and leaf samples were washed with de-ionized water. Subsequently, these tissue samples were dried in oven for $1 \mathrm{~h}$ at $105^{\circ} \mathrm{C}$ to inactivate enzymes and to denature proteins rapidly. Then samples were incubated at $70^{\circ} \mathrm{C}$ for $3 \mathrm{~d}$. Dried tissues were weighed and digested with nitric acid. The $\mathrm{Pb}$ concentration of each sample was determined by flame atomic absorbance spectrometry (ZEEnit-700p, Jena, Germany) and expressed in $\mathrm{mg}(\mathrm{Pb}) \mathrm{kg}^{-1}$ (dry mass, DM).

Chl content: Leaf samples were cut into small pieces, less than $2 \times 5 \mathrm{~mm}$. Then, $0.1 \mathrm{~g}$ of fresh mass (FM) of each sample was precisely weighed and placed in a flask with $10 \mathrm{~mL}$ of mixed solution [acetone:ethanol:water with a ratio of $4.5: 4.5: 1(\mathrm{v} / \mathrm{v} / \mathrm{v})$, respectively]. All flasks were placed in darkness for $24 \mathrm{~h}$, and shaken once every $4 \mathrm{~h}$ during this period. Absorbance of the supernatant was recorded at 645 and $663 \mathrm{~nm}$ using a spectrophotometer
2009). Although some information on strong Pb tolerance of $M$. rubra seedling has been provided, the relationship between $\mathrm{Pb}$ and the functioning of the photosynthetic apparatus needed further detailed analyses.

The present study investigated the effects of elevated $\mathrm{Pb}$ stress on $\mathrm{Pb}$ accumulation and photosynthesis of M. rubra seedlings. Our specific objective was to determine and analyze the changes in Chl content, gas exchange, and $\mathrm{Chl}$ fluorescence parameters in order to evaluate the tolerance of $M$. rubra seedlings to serious $\mathrm{Pb}$ stress over a long period.

(UV-1800, Shimadzu Corp., Kyoto, Japan). Chl content in leaf samples was calculated according to Arnon (1949). The Chl $a / b$ ratio was defined as the ratio of the mean Chl $a$ and mean $\mathrm{Chl} b$ content.

Gas-exchange parameters were measured at 10 and $30 \mathrm{~d}$ of the $\mathrm{Pb}$ treatment. The light-saturated net photosynthetic rate $\left(P_{\mathrm{N}}\right)$, stomatal conductance $\left(g_{\mathrm{s}}\right)$, transpiration rate $(E)$, and intercellular $\mathrm{CO}_{2}$ concentration $\left(C_{\mathrm{i}}\right)$ of young, fully expanded leaves were measured using a portable photosynthesis system ( $L I-6400, \mathrm{Li}-\mathrm{Cor}$, Inc., Lincoln, NE, USA). Water-use efficiency (WUE) was defined as the ratio of $P_{\mathrm{N}} / E$. Artificial illumination was supplied to each leaf from a red/blue LED light source, and $340 \mathrm{~cm}^{3} \mathrm{~m}^{-3}$ of $\mathrm{CO}_{2}$ was supplied by a $6400 \mathrm{CO}_{2}$ mixer ( $\mathrm{Li}-\mathrm{Cor}$, Inc., Lincoln, NE, USA). Measurements were made between 11:00-13:00 h of the local time.

Chl fluorescence parameters were measured at a fixed time $(11: 00 \mathrm{~h})$ by a portable fluorimeter (PAM-2000, Walz, Effeltrich, Germany). To obtain the maximum potential fluorescence of PSII, the leaves were adapted to darkness for 15 min before the measurements. The minimum fluorescence level in the dark-adapted state $\left(\mathrm{F}_{0}\right)$ was measured based on the intensity of the modulated light, which was sufficiently low and caused no significant variable fluorescence. When the actinic light was removed, the minimal fluorescence level in the lightadapted state $\left(\mathrm{F}_{0}{ }^{\prime}\right)$ was measured by illuminating the leaves with $3 \mathrm{~s}$ of far red light. The maximal fluorescence levels in the dark-adapted $\left(\mathrm{F}_{\mathrm{m}}\right)$ and light-adapted $\left(\mathrm{F}_{\mathrm{m}}{ }^{\prime}\right)$ states were determined before and after the actinic illumination by applying 1-s saturating 'white light' to close all of the reaction centers. The following values were determined: the maximum quantum yield of PSII photochemistry: $\mathrm{F}_{\mathrm{v}} / \mathrm{F}_{\mathrm{m}}=\left(\mathrm{F}_{\mathrm{m}}-\mathrm{F}_{0}\right) / \mathrm{F}_{\mathrm{m}}$, the effective quantum yield of PSII photochemistry: $\Phi_{\mathrm{PSII}}=\left(\mathrm{F}_{\mathrm{m}}{ }^{\prime}-\mathrm{F}_{\mathrm{s}}\right) / \mathrm{F}_{\mathrm{m}}{ }^{\prime}$, photochemical quenching coefficient: $\mathrm{q}_{\mathrm{P}}=\left(\mathrm{F}_{\mathrm{m}}{ }^{\prime}-\mathrm{F}_{\mathrm{s}}\right) /\left(\mathrm{F}_{\mathrm{m}}{ }^{\prime}-\mathrm{F}_{0}{ }^{\prime}\right)$, and nonphotochemical quenching coefficient: $\mathrm{q}_{\mathrm{N}}=\left(\mathrm{F}_{\mathrm{m}}-\mathrm{F}_{\mathrm{m}}{ }^{\prime}\right) /\left(\mathrm{F}_{\mathrm{m}}-\mathrm{F}_{0}{ }^{\prime}\right)$. 


\section{Results}

Pb accumulation in leaves and stems of $M$. rubra seedlings increased significantly with increasing external $\mathrm{Pb}$ concentrations at $30 \mathrm{~d}$ after the beginning of $\mathrm{Pb}$ exposure. After the treatment by $2 \mathrm{mM} \mathrm{Pb}$, only 56.09 and $86.42 \mathrm{mg}(\mathrm{Pb}) \mathrm{kg}^{-1}$ accumulated in leaves and stems, respectively. However, the corresponding values at $4 \mathrm{mM}$ $\mathrm{Pb}$ were substantially higher by up to 9.9 and 34.5 times of the above amounts. After the treatment by $6 \mathrm{mM} \mathrm{Pb}$, the concentration of $\mathrm{Pb}$ reached 1,211 and 3,474 mg kg-1 in leaf and stem tissues, respectively (Table 1). The ratios of $\mathrm{Pb}$ in leaf to stem tissues affected by 2,4 , and $6 \mathrm{mM} \mathrm{Pb}$ were $0.64,0.18$, and 0.34 , respectively.

Chl concentration: Chlorosis is a general symptom of heavy metal damage in plants. At $10 \mathrm{~d}$ after the treatment, the contents of total Chl and Chl $a$ were significantly lower than that in controls, but only in the seedlings exposed to $6 \mathrm{mM} \mathrm{Pb}$ (Table 2), while Chl $b$ content was stable under all of the $\mathrm{Pb}$ concentrations. It should be noted that a significant reduction of the $\mathrm{Chl} a / b$ ratio was observed only in the seedlings after $10 \mathrm{~d}$ of their exposure to $6 \mathrm{mM} \mathrm{Pb}$. After $30 \mathrm{~d}$ from the exposure, the content of total Chl, Chl $a$, and $\mathrm{Chl} b$ did not change at $2 \mathrm{mM} \mathrm{Pb}$, and decreased significantly at 4-6 $\mathrm{mM} \mathrm{Pb}$ (Table 2). For $\mathrm{Pb}$ exposure over $2 \mathrm{mM}$, the $\mathrm{Chl}$ content was reduced in a concentration- and time-dependent manner. Compared with controls, the Chl $a$ and $\mathrm{Chl} b$ contents were reduced by 24.9 and $12.3 \%$, respectively, at $30 \mathrm{~d}$ after the treatment with $6 \mathrm{mM} \mathrm{Pb}$ (Table 2).
Gas exchange: At $10 \mathrm{~d}$ after the treatment, $P_{\mathrm{N}}$ decreased with the increased $\mathrm{Pb}$ concentration except for $2 \mathrm{mM} \mathrm{Pb}$ exposure. However, $g_{\mathrm{s}}, E, C_{\mathrm{i}}$, and WUE did not change compared with controls even at $6 \mathrm{mM} \mathrm{Pb}$ (Table 3). At $30 \mathrm{~d}$ after the treatment, $P_{\mathrm{N}}, g_{\mathrm{s}}, E$, and WUE were reduced with the increasing $\mathrm{Pb}$ stress, but $C_{\mathrm{i}}$ showed a significantly increasing trend. $P_{\mathrm{N}}, E, g_{\mathrm{s}}$, and WUE under $6 \mathrm{mM} \mathrm{Pb}$ decreased by $69.3,57.5,56.5$, and $30.9 \%$ compared with controls, respectively, at $30 \mathrm{~d}$ after the treatment, while $C_{\mathrm{i}}$ increased by $22.4 \%$ under the same conditions (Table 3 ).

Chl fluorescence: During the first $10 \mathrm{~d}$ of the treatment, $\mathrm{F}_{0}, \mathrm{~F}_{\mathrm{v}} / \mathrm{F}_{\mathrm{m}}, \Phi_{\mathrm{PSII}}, \mathrm{q}_{\mathrm{P}}$, and $\mathrm{q}_{\mathrm{N}}$ remained stable, which indicated the highest $\mathrm{Pb}$ supply had no effect on $\mathrm{Chl}$ fluorescence of the seedlings for a relative short time period. At $30 \mathrm{~d}$ of the treatment, $F_{0}$ showed an increasing trend with 4 and $6 \mathrm{mM} \mathrm{Pb}$, which was likely due to inactivation of reaction centers (Fig. $1 A$ ). The $\mathrm{F}_{\mathrm{v}} / \mathrm{F}_{\mathrm{m}}$ value is an indicator of the maximum primary photosynthetic quantum efficiency of PSII, while $\Phi_{\text {PSII }}$ measures the effective yield of light quantum absorbed by PSII that is used in photochemistry. At $30 \mathrm{~d}$ after the treatment, $F_{v} / F_{m}$ reached $0.79-0.83$ at each $\mathrm{Pb}$ treatment, similar to those of the control, while $\Phi_{\text {PSII }}$ decreased significantly with a further increase of the $\mathrm{Pb}$ concentration, which was accompanied by the decline of $\mathrm{q}_{\mathrm{P}}$ and $\mathrm{q}_{\mathrm{N}}$. Under $6 \mathrm{mM} \mathrm{Pb}$ for $30 \mathrm{~d}$, $\Phi_{\mathrm{PSII}}, \mathrm{q}_{\mathrm{P}}$, and $\mathrm{q}_{\mathrm{N}}$ decreased by $48.6,42.8$, and $25.9 \%$ compared with the controls, respectively (Fig. 1).

Table 1. Pb contents in Myrica rubra seedlings treated with $0,2,4$, or $6 \mathrm{mM} \mathrm{Pb}$ for $30 \mathrm{~d}$. Results are means $\pm \mathrm{SD}(n=3)$. Means with different letters within the same column are significantly different from one another $(p<0.05)$. DM - dry mass.

\begin{tabular}{llll}
\hline $\begin{array}{l}\text { Treatment time } \\
\text { [d] }\end{array}$ & $\begin{array}{l}\text { Pb concentration } \\
{[\mathrm{mM}]}\end{array}$ & $\begin{array}{l}\mathrm{Pb} \text { content }\left[\mathrm{mg} \mathrm{kg}^{-1}(\mathrm{DM})\right] \\
\text { Leaf }\end{array}$ \\
\hline 30 & 0 & $55.34 \pm 7.72^{\mathrm{c}}$ & $0^{\mathrm{c}}$ \\
& 2 & $86.42 \pm 4.34^{\mathrm{c}}$ & $56.09 \pm 6.44^{\mathrm{c}}$ \\
& 4 & $2,985 \pm 66^{\mathrm{b}}$ & $552 \pm 34.18^{\mathrm{b}}$ \\
& 6 & $3,473 \pm 165^{\mathrm{a}}$ & $1,210 \pm 55^{\mathrm{a}}$ \\
\hline
\end{tabular}

Table 2. Chlorophyll (Chl) content and $\mathrm{Chl} a / b$ ratio of Myrica rubra seedlings treated with 0,2 , 4, or $6 \mathrm{mM} \mathrm{Pb}$ for 10 and $30 \mathrm{~d}$. The $\mathrm{Chl} a / b$ ratio was defined as the ratio of mean $\mathrm{Chl} a$ and mean $\mathrm{Chl} b$ content. Results are means $\pm \operatorname{SD}(n=3)$. Means with different letters within the same column are significantly different from one another $(p<0.05)$. FM - fresh mass.

\begin{tabular}{llllll}
\hline $\begin{array}{l}\text { Treatment time } \\
\text { [d] }\end{array}$ & $\begin{array}{l}\mathrm{Pb} \text { treatment } \\
{[\mathrm{mM}]}\end{array}$ & \multicolumn{2}{l}{$\begin{array}{l}\text { Chl content } \\
\text { Total Chl }\end{array}$} & $\mathrm{mg} \mathrm{kg}(\mathrm{FM})]$ & $\mathrm{Chl} a / b$ \\
\hline 10 & 0 & $5.80 \pm 0.53^{\mathrm{a}}$ & $4.10 \pm 0.11^{\mathrm{ab}}$ & $1.71 \pm 0.13^{\mathrm{a}}$ & 2.40 \\
& 2 & $6.18 \pm 0.32^{\mathrm{a}}$ & $4.32 \pm 0.07^{\mathrm{a}}$ & $1.92 \pm 0.11^{\mathrm{a}}$ & 2.25 \\
& 4 & $5.52 \pm 0.40^{\mathrm{ab}}$ & $3.91 \pm 0.28^{\mathrm{ab}}$ & $1.66 \pm 0.14^{\mathrm{a}}$ & 2.35 \\
& 6 & $4.91 \pm 0.04^{\mathrm{b}}$ & $3.50 \pm 0.03^{\mathrm{b}}$ & $1.96 \pm 0.35^{\mathrm{a}}$ & 1.79 \\
30 & 0 & $5.71 \pm 0.29^{\mathrm{a}}$ & $4.18 \pm 0.16^{\mathrm{a}}$ & $1.54 \pm 0.08^{\mathrm{ab}}$ & 2.72 \\
& 2 & $5.71 \pm 0.19^{\mathrm{a}}$ & $4.08 \pm 0.12^{\mathrm{a}}$ & $1.58 \pm 0.06^{\mathrm{a}}$ & 2.58 \\
& 4 & $4.53 \pm 0.17^{\mathrm{b}}$ & $3.28 \pm 0.11^{\mathrm{b}}$ & $1.34 \pm 0.05^{\mathrm{b}}$ & 2.46 \\
& 6 & $4.41 \pm 0.13^{\mathrm{b}}$ & $3.14 \pm 0.08^{\mathrm{b}}$ & $1.35 \pm 0.01^{\mathrm{b}}$ & 2.32 \\
\hline
\end{tabular}




\section{Discussion}

Photosynthesis serves as an important determinant of the yield, but is very vulnerable to heavy metal stress. $\mathrm{Pb}^{2+}$ inhibits the entire process of photosynthesis in plants, including photochemical (Fargašová 2001, Wu et al. 2008a) and carbon-based reactions (Wu et al. 2008b). Changes of photosynthetic indices can be used to determine a tolerance of a plant species to $\mathrm{Pb}$. The present study dealt with the response of photosynthesis in $M$. rubra seedlings to severe $\mathrm{Pb}$ stress. Our results may provide important information related to a remediation of $\mathrm{Pb}$ polluted soils.

$\mathrm{Zu}$ et al. (2004) reported that the normal content of $\mathrm{Pb}$ in shoots of plants is $5 \mathrm{mg} \mathrm{kg}$. A plant that can accumulates $\mathrm{Pb}$ concentrations $>1,000 \mathrm{mg} \mathrm{kg}^{-1}$, when grown on metal rich soils, is called a hyperaccumulator of $\mathrm{Pb}$ (Baker et al. 1989, Ali et al. 2013). Aside from their strong ability to adsorb $\mathrm{Pb}$, hyperaccumulators should have positive mechanism(s) for translocating larger than average amounts of metals up to the leaves rather than moving metals into the stems or roots (Nicoletta and Navari-Izzo 2011). A large body of evidence indicates that two factors can create a potential for a hyperaccmulator to accumulate greater amounts of metals than average in shoots than roots. These are a positive upward transport of heavy metals in plants and a reliance on enhanced xylem loading and chelation of metals along with other small molecule organic compounds (Axelsen and Palmgren 1998, Mils et al. 2003, Callahan et al. 2006). At $6 \mathrm{mM} \mathrm{Pb}$ treatment, the accumulation of $\mathrm{Pb}$ in leaf and stem tissues reached 1,211 and 3,474 $\mathrm{mg} \mathrm{kg}^{-1}$, respectively (Table 1). This observation suggests that seedlings of $M$. rubra have a relatively strong ability to absorb and accumulate $\mathrm{Pb}$. However, the seedlings of $M$. rubra stored more $\mathrm{Pb}$ in stems than in leaves. The ratios of leaf and stem $\mathrm{Pb}$ were less than 1 which suggested that the upward transportation mechanism from stem to leaf of $M$. rubra depended passively on the concentration of $\mathrm{Pb}$ supplied, and was not closely related to the positive upward transportation of heavy metal as expected for the potential hyperaccumulator.
The total Chl, Chl $a$, and Chl $b$ content of M. rubra remained stable during $30 \mathrm{~d}$ of $2 \mathrm{mM} \mathrm{Pb}$ treatment. However, with $4 \mathrm{mM} \mathrm{Pb}$, the total $\mathrm{Chl}, \mathrm{Chl} a$, and $\mathrm{Chl} b$ content declined in the seedlings after $30 \mathrm{~d}$. Under the treatment with $6 \mathrm{mM} \mathrm{Pb}$, the $\mathrm{Chl}$ content decreased in seedlings at day 10 , but the $\mathrm{Chl} b$ content did not change. Therefore, the effects of $\mathrm{Pb}$ on the $\mathrm{Chl}$ concentration largely depended on the $\mathrm{Pb}$ concentrations and the time of exposure to $\mathrm{Pb}$ stress. In the present study, our data suggest that the major reason for the decrease of total $\mathrm{Chl}$ and $\mathrm{Chl} a / b$ was the decline of $\mathrm{Chl} a$. According to Prasad et al. (1998), $\mathrm{Pb}$ induced a greater decline in total $\mathrm{Chl}$ and $\mathrm{Chl} a$ content than that in the $\mathrm{Chl} b$ content and the $\mathrm{Chl} a / b$ ratio. Gajić et al. (2009) assessed the tolerance of Ligustrum ovalifolium Hassk. to $\mathrm{Pb}$ and found that the $\mathrm{Chl} a$ was more sensitive to $\mathrm{Pb}$ than $\mathrm{Chl} b$. Li et al. (2012) observed that increased $\mathrm{Pb}$ supply resulted in the decrease in Chl $a$ and carotenoids in the seedlings of rice, but no decrease in $\mathrm{Chl} b$ was observed. Our results agree with the above findings. It is generally accepted that this heavy metal reduces the Chl content by inhibiting the activity of enzymes that participate in Chl synthesis (Moustakas 1994). The replacement of the central Mg in Chl molecule with $\mathrm{Pb}$ is another explanation for the decline in $\mathrm{Chl}$ content (Prasad, 1998). Wu et al. (2008a) also speculated that $\mathrm{Pb}$ might prevent photosynthetic light harvesting in the affected $\mathrm{Chl}$ molecules by the substitution of $\mathrm{Mg}$ with Ca. Shakoor et al. (2014) proposed that the decline in Chl content under $\mathrm{Pb}$ stress was caused by an oxidative response, because citric acid, an antioxidant, induced diminution of damage in Brassica napus under Pb stress. Our previous research demonstrated that the $2 \mathrm{mM} \mathrm{Pb}^{2+}$ treatment had no apparent effect on the content of total soluble proteins, but increased the activities of superoxide dismutase and peroxidase as well as the content of soluble sugars (He et al. 2009). Thus, it was suggested that the antioxidant defense mechanism in the seedlings of M. rubra may be involved in the protection of Chl against $\mathrm{Pb}$ stress.

Table 3. The change of light-saturated net photosynthetic rate $\left(P_{\mathrm{N}}\right)$, transpiration rate $(E)$, stomatal conductance $\left(g_{\mathrm{s}}\right)$, internal $\mathrm{CO}_{2}$ concentration $\left(C_{\mathrm{i}}\right)$, and water-use efficiency (WUE) of Myrica. rubra seedlings treated with $0,2,4$, or $6 \mathrm{mM} \mathrm{Pb}$ after 10 and $30 \mathrm{~d}$. Water-use efficiency (WUE) was defined as the ratio of $P_{\mathrm{N}} / E$. Results are means $\pm \mathrm{SD}(n=3)$. Means with different letters within the same column are significantly different from one another $(p<0.05)$.

\begin{tabular}{|c|c|c|c|c|c|c|}
\hline $\begin{array}{l}\text { Treatment } \\
\text { time }[\mathrm{d}]\end{array}$ & $\begin{array}{l}\mathrm{Pb} \text { treatment } \\
{[\mathrm{mM}]}\end{array}$ & $\begin{array}{l}P_{\mathrm{N}} \\
{\left[\mu \mathrm{mol}\left(\mathrm{CO}_{2}\right) \mathrm{m}^{-2} \mathrm{~s}^{-1}\right]}\end{array}$ & $\begin{array}{l}E \\
{\left[\operatorname{mmol}\left(\mathrm{H}_{2} \mathrm{O}\right) \mathrm{m}^{-2} \mathrm{~s}^{-1}\right]}\end{array}$ & $\begin{array}{l}g_{\mathrm{s}} \\
{\left[\mathrm{mol}\left(\mathrm{H}_{2} \mathrm{O}\right) \mathrm{m}^{-2} \mathrm{~s}^{-1}\right]}\end{array}$ & $\begin{array}{l}C_{\mathrm{i}} \\
]\left[\mu \mathrm{mol}\left(\mathrm{CO}_{2}\right) \mathrm{mol}^{-1}\right.\end{array}$ & $\begin{array}{l}\text { WUE } \\
\left.{ }^{1}\right]\left[\mathrm{mol}\left(\mathrm{CO}_{2}\right) \mathrm{mol}\left(\mathrm{H}_{2} \mathrm{O}\right)^{-1}\right]\end{array}$ \\
\hline \multirow[t]{4}{*}{10} & 0 & $3.27 \pm 0.22^{\mathrm{a}}$ & $0.875 \pm 0.068^{\mathrm{a}}$ & $45.68 \pm 2.83^{\mathrm{a}}$ & $281.95 \pm 19.50^{\mathrm{a}}$ & $3.74 \pm 0.41^{\mathrm{a}}$ \\
\hline & 2 & $3.00 \pm 0.42^{\mathrm{ab}}$ & $0.885 \pm 0.133^{\mathrm{a}}$ & $46.00 \pm 7.00^{\mathrm{a}}$ & $284.16 \pm 29.37^{\mathrm{a}}$ & $3.39 \pm 0.33^{\mathrm{a}}$ \\
\hline & 4 & $2.58 \pm 0.21^{\mathrm{b}}$ & $0.806 \pm 0.129^{\mathrm{a}}$ & $41.17 \pm 3.17^{\mathrm{a}}$ & $298.53 \pm 5.94^{\mathrm{a}}$ & $3.20 \pm 0.15^{\mathrm{a}}$ \\
\hline & 6 & $2.55 \pm 0.31^{b}$ & $0.736 \pm 0.064^{\mathrm{a}}$ & $40.16 \pm 3.14^{\mathrm{a}}$ & $309.26 \pm 10.71^{\mathrm{a}}$ & $3.46 \pm 0.39^{\mathrm{a}}$ \\
\hline \multirow[t]{4}{*}{30} & 0 & $3.22 \pm 0.26^{\mathrm{a}}$ & $0.400 \pm 0.058^{\mathrm{a}}$ & $43.33 \pm 6.83^{\mathrm{a}}$ & $274.10 \pm 8.33^{b}$ & $8.05 \pm 0.39^{\mathrm{a}}$ \\
\hline & 2 & $1.68 \pm 0.43^{\mathrm{b}}$ & $0.236 \pm 0.017^{b}$ & $25.17 \pm 0.65^{\mathrm{b}}$ & $303.40 \pm 10.01^{\mathrm{ab}}$ & $7.13 \pm 0.12^{\mathrm{a}}$ \\
\hline & 4 & $1.37 \pm 0.31^{\mathrm{b}}$ & $0.251 \pm 0.030^{\mathrm{b}}$ & $27.50 \pm 3.50^{\mathrm{b}}$ & $331.70 \pm 20.59^{a}$ & $5.46 \pm 0.47^{b}$ \\
\hline & 6 & $0.95 \pm 0.24^{b}$ & $0.170 \pm 0.032^{b}$ & $18.84 \pm 2.83^{\mathrm{b}}$ & $335.60 \pm 15.64^{\mathrm{a}}$ & $5.56 \pm 0.36^{\mathrm{b}}$ \\
\hline
\end{tabular}




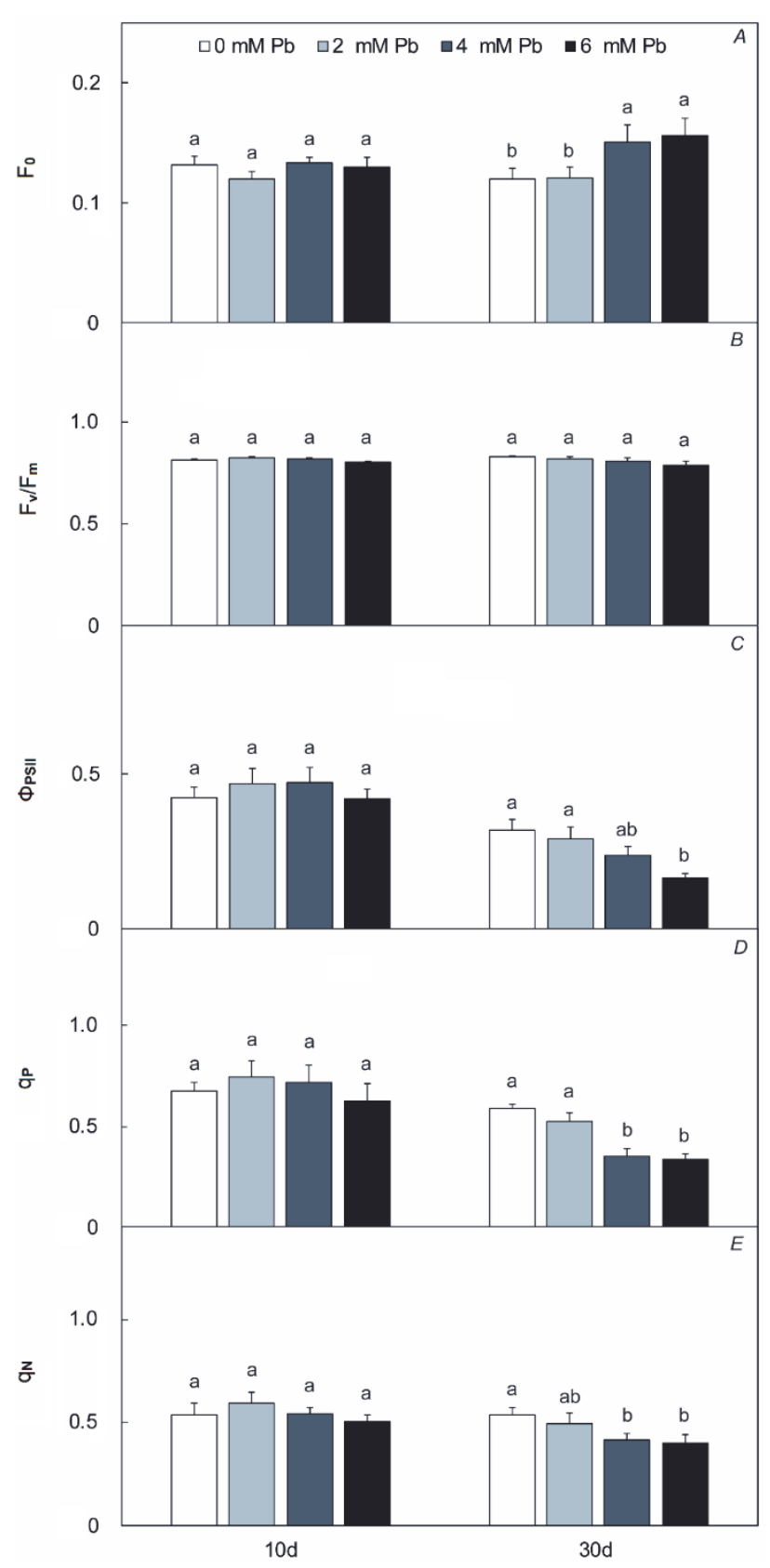

Fig. 1. The change of minimal fluorescence $\left(\mathrm{F}_{0}\right)$, maximal quantum yield of PSII photochemistry $\left(\mathrm{F}_{\mathrm{v}} / \mathrm{F}_{\mathrm{m}}\right)$, effective photochemical efficiency of PSII (ФPSII), photochemical quenching coefficient $(\mathrm{q})$, and nonphotochemical quenching coefficient $\left(\mathrm{q}_{\mathrm{N}}\right.$ ) of Myrica rubra seedlings treated with $0,2,4$, or $6 \mathrm{mM} \mathrm{Pb}$ for 10 and $30 \mathrm{~d}$. Bars are the means $\pm \mathrm{SD}(n=3)$. Bars with different letters are significantly different from one another $(p<0.05)$.

$P_{\mathrm{N}}$ is a combined reflection of the comprehensive process of photosynthesis, including light trapping, electron transfer, photosynthetic phosphorylation, and $\mathrm{CO}_{2}$ assimilation. Although the photosynthetic parameters $\left(g_{\mathrm{s}}, E, C_{\mathrm{i}}\right.$, and WUE) and $\mathrm{Chl}$ fluorescence parameters $\left(\mathrm{F}_{0}\right.$, $\mathrm{F}_{\mathrm{v}} / \mathrm{F}_{\mathrm{m}}, \Phi_{\mathrm{PSII}}, \mathrm{q}_{\mathrm{P}}$, and $\left.\mathrm{q}_{\mathrm{N}}\right)$ in the seedlings after $10 \mathrm{~d}$ of $4 \mathrm{mM}$ and $6 \mathrm{mM} \mathrm{Pb}$ treatments showed no significant differences when compared with the control, $P_{\mathrm{N}}$ declined significantly under the same $\mathrm{Pb}$ stress. $P_{\mathrm{N}}$ was more sensitive to $\mathrm{Pb}$ than the other photosynthetic parameters (i.e., $g_{\mathrm{s}}, E, C_{\mathrm{i}}$, and WUE). The reductions of Chl $a$ content at $10 \mathrm{~d}$ after the treatment suggest that the decline of $P_{\mathrm{N}}$ in a relatively short time of treatment might be caused by damage of Chl. Chl is more sensitive to $\mathrm{Pb}$ than stomatal regulation and photochemical reactions. At $30 \mathrm{~d}$ after the treatment, the inhibition of $P_{\mathrm{N}}$ induced by $\mathrm{Pb}$ was in accordance with the decreasing trends of $g_{\mathrm{s}}$ and $E$, which indicated that stomatal closure was another factor causing the decrease in $P_{\mathrm{N}}$ for a relatively longer time period apart from $\mathrm{Chl}$ damage. Ahmad et al. (2008) treated the seedlings of mung bean (Vigna radiata) by $50 \mathrm{mg}(\mathrm{Pb}) \mathrm{L}^{-1}$ for $10 \mathrm{~d}$ and concluded that stomatal limitation was the main factor causing photosynthetic inhibition by $\mathrm{Pb}$. Li et al. (2012) also obtained similar results in rice seedlings treated by 50-200 $\mu \mathrm{M} \mathrm{Pb}$ for $14 \mathrm{~d}$. In contrast, the reduced $g_{\mathrm{s}}$ did not lead to a decrease in $C_{\mathrm{i}}$. Intercellular $\mathrm{CO}_{2}$ concentration represents a balance of $\mathrm{CO}_{2}$ between $\mathrm{CO}_{2}$ entering through the stoma and $\mathrm{CO}_{2}$ consumed by assimilation. The increased in $C_{\mathrm{i}}$ and the decrease in $g_{\mathrm{s}}$ in the seedlings at $30 \mathrm{~d}$ after the treatment with $4-6 \mathrm{mM} \mathrm{Pb}$ suggests that carbon assimilation was inhibited; this means the drastic $P_{\mathrm{N}}$ reduction over longer time periods (Farquhar and Sharkey. 1982, Koyro et al. 2013). Rubisco is the most important enzyme related to carbon assimilation in photosynthesis. Van Assche and Clijsters (1990) reported that $\mathrm{Pb}$ inhibited the activity of Rubisco. Wu et al. (2008b) found that $\mathrm{Ca}^{2+}$-ATPase, Rubisco activase, and the carboxylation activity of Rubisco were inhibited in $\mathrm{Pb}$ treated spinach; this suggested that $\mathrm{Pb}$ impaired $\mathrm{CO}_{2}$ assimilation by inhibiting the transformation from active chemical energy to stable forms of energy.

The $\mathrm{F}_{0}$ is an emission from excited antenna Chl of PSII, which represents energy liberation in competition with excitation energy transfer to PSII. When PSII maintains in active state, $F_{0}$ is minimal. The increase of $F_{0}$ in the seedlings under $4-6 \mathrm{mM} \mathrm{Pb}$ for $30 \mathrm{~d}$ indicated that energy transfer from the LHC to PSII was severely inhibited. Because $\mathrm{F}_{0}$ originates from Chl $a$ antennae in the LHCII (Karukstis 1991), it is supposed that the increase of $F_{0}$ might be related to the loss of Chl $a$ observed in the seedlings under the same $\mathrm{Pb}$ stress (Table 2). The measure of maximum photochemical efficiency $\left(\mathrm{F}_{\mathrm{v}} / \mathrm{F}_{\mathrm{m}}\right)$ can be used to estimate the potential efficiency of the primary photochemical reactions when all of the PSII centers were open. The decline of $F_{v} / F_{m}$ reflects the structural damage to PSII and an increase in nonphotochemical energy dissipation as heat. Björkman and Demmig (1987) proposed that if $F_{v} / F_{m}>0.8$, a plant is healthy and the severe damage of PSII does not occur. In the present study, $\mathrm{F}_{\mathrm{v}} / \mathrm{F}_{\mathrm{m}}$ remained stable within $0.79-0.83$ during the $30 \mathrm{~d}$ of $\mathrm{Pb}$ treatments. We expected that the $\mathrm{Pb}$ of $2-6 \mathrm{mM}$ for $30 \mathrm{~d}$ would not cause severe damage to PSII efficiency in leaves of the treated seedlings. $\Phi_{\text {PSII }}$ measures the actual 
efficiency of the activity of PSII under stress. At $10 \mathrm{~d}$ after the treatment, $\Phi_{\text {PSII }}$ was virtually unaltered by $\mathrm{Pb}$. At $30 \mathrm{~d}$, a significant reduction of $\Phi_{\text {PSII }}$ was observed only in the seedlings under $6 \mathrm{mM} \mathrm{Pb}$ stress. Furthermore, $\Phi_{\text {PSII }}$ was more sensitive than $F_{v} / F_{m}$ in seedlings with the same $\mathrm{Pb}$ treatments. A similar relationship between $\Phi_{\mathrm{PSII}}$ and $\mathrm{F}_{\mathrm{v}} / \mathrm{F}_{\mathrm{m}}$ has also been reported for Vigna umbellata seedlings under 0.2-0.6 mM Mn (Subrahmanyam and Rathore 2000) and in seedlings of Amaranthus tricolor under 0.5-4.0 $\operatorname{mmol}(\mathrm{Cu}) \mathrm{kg}^{-1}$ (Ke et al. 2007). Reduction of $\Phi_{\text {PSII }}$ could be explained as a decreased capacity of the plants to assimilate $\mathrm{CO}_{2}$ or as a result of oxidative phosphorylation (Subrahmanyam and Rathore 2000). The qp indicated the use of absorbed light energy through photochemical processes, and could be used to approximate the proportion of PSII reaction centers that are open. The $\mathrm{q}_{\mathrm{N}}$ reflected excess nonradiative energy dissipation as heat from the photosynthetic apparatus that could minimize the production of oxidant molecules and protect the plant against photo-oxidative damage. The sum of the two quenching parameters should be 1, i.e., $\mathrm{q}_{\mathrm{P}}$ and $\mathrm{q}_{\mathrm{N}}$ represent full quenching, and the decline of $\mathrm{q}_{\mathrm{P}}$ was accompanied by an increase of $\mathrm{q}_{\mathrm{N}}$ induced by light, temperature, heavy metal, or other environmental stress. However, other reports contradict this finding. Meneguelli-Souza et al. (2016) observed that $\mathrm{q}_{\mathrm{P}}$ and $\mathrm{q}_{\mathrm{N}}$ decreased significantly in water hyacinth (Eichhornia crassipes) on day 4 after treatment in the presence of 2.0 and $20 \mathrm{mg}\left(\mathrm{As}^{5+}\right) \mathrm{L}^{-1}$. Tanyolac et al. (2007) found that both $\mathrm{q}_{\mathrm{P}}$ and $\mathrm{q}_{\mathrm{N}}$ showed decreasing trends in maize leaves exposed to $1.5 \mathrm{mM} \mathrm{Cu}$ for $12 \mathrm{~d}$. Those authors suggested that the observed decrease in $\mathrm{q}_{\mathrm{N}}$ might be associated with the AOS generation caused by $\mathrm{Cu}$ stress. Jamil et al. (2007) found

\section{References}

Ahmad M.S.A., Hussain M., Ijaz S. et al.: Photosynthetic performance of two mung bean (Vigna radiata) cultivars under lead and copper stress. - Int. J. Agr. Bio. 10: 167-172, 2008.

Ali H., Khan E., Sajad M.A.: Phytoremediation of heavy metalsconcepts and applications. - Chemosphere 91: 869-881, 2013.

Arnon D.I.: Copper enzymes in isolated chloroplasts. Polyphenoloxidase in Beta vulgaris. - Plant Physiol. 24: 1-15, 1949.

Axelsen K.B., Palmgren M.G.: Inventory of the superfamily of P-Type ion pumps in Arabidopsis. - Plant Physiol. 126: 696706, 2001.

Björkman O., Demmig B.: Photon yield of $\mathrm{O}_{2}$ evolution and chlorophyll fluorescence characteristics at $77 \mathrm{~K}$ among vascular plants of diverse origins. - Planta 170: 489-504, 1987.

Callahan D.L., Baker A.J.M., Kolev S.D. et al.: Metal ion ligands in hyper-accumulating plants. - J. Biol. Inorg. Chem. 11: 2-12, 2006.

Caparròs S., Diaz M.J., Ariza J. et al.: New perspectives for Paulownia fortunei $\mathrm{L}$. valorization of the autohydrolysis and pulping processes. - Bioresource Technol. 99: 741-749, 2008.

Doumett S., Lamperi L., Checchini L. et al.: Heavy metal distribution between contaminated soil and Paulownia tomentosa in a pilot-scale assisted phytoremediation study: that $\mathrm{q}_{\mathrm{P}}$ and $\mathrm{q}_{\mathrm{N}}$ declined in radish as the salt concentration increased, and concluded that stomatal closure by $\mathrm{NaCl}$ induced the inhibition of $\mathrm{q}_{\mathrm{N}}$.

In our previous study, only one of three seedlings of M. rubra survived for 2 months under $5 \mathrm{mM} \mathrm{Pb}$ (He et al. 2004). Therefore, the treatment with $2-6 \mathrm{mM} \mathrm{Pb}$ would be expected to result in relatively serious damage to the seedlings of $M$. rubra. The Chl content along with photosynthetic and Chl fluorescence parameters of $M$. rubra seedlings exposed to $2-6 \mathrm{mM} \mathrm{Pb}$ were investigated in the present study over a period of $30 \mathrm{~d}$ to understand the tolerance of photosynthesis in woody plants to serious $\mathrm{Pb}$ pollution conditions, such as waste water discharge from mining enterprises. Chl $a$ was more strongly affected by $\mathrm{Pb}$ than $\mathrm{Chl} b$ in $M$. rubra seedlings. In the case of photosynthetic parameters, $P_{\mathrm{N}}$ was more sensitive than $g_{\mathrm{s}}$, $E$, and $C_{\mathrm{i}}$ to $\mathrm{Pb}$ stress. With an increased amount of $\mathrm{Pb}, P_{\mathrm{N}}$ was observed to initially decline with $4 \mathrm{mM} \mathrm{Pb}$ at $10 \mathrm{~d}$ after the treatment. The inhibition of $\mathrm{Chl} a$ content was observed with $6 \mathrm{mM} \mathrm{Pb}$ at $10 \mathrm{~d}$ after the treatment, while $g_{\mathrm{s}}$ and $E$ declined with $2-4 \mathrm{mM}$ Pb stress at $30 \mathrm{~d}$ after the treatment. Additionally, the declines of Chl fluorescence parameters occurred finally with $4-6 \mathrm{mM} \mathrm{Pb} 30 \mathrm{~d}$ after the treatment.

In conclusion, as M. rubra exhibited a strong ability to accumulate $\mathrm{Pb}$ and showed tolerance to $2 \mathrm{mM} \mathrm{Pb}$. This species can provide a good plant material for the phytoremediation of soil with a low concentration of $\mathrm{Pb}$. However, if $\mathrm{Pb}$ concentration exceeded $2 \mathrm{mM}$, the $\mathrm{Chl}$ content, stomatal conductance, and PSII function were inhibited. It indicates that the use of M. rubra is limited for the remediation of soils severely polluted with $\mathrm{Pb}$.

influence of different complexing agents. - Chemosphere 72: 1481-1490, 2008.

Drazkiewicz M.: Chlorophyllase: occurrence, functions, mechanism of action, effects of external and internal factors (Review). - Photosynthetica 30: 321-331, 1994.

Fargašová A.: Phytotoxic effects of $\mathrm{Cd}, \mathrm{Zn}, \mathrm{Pb}, \mathrm{Cu}$ and $\mathrm{Fe}$ on Sinapis alba L. seedlings and their accumulation in roots and shoots. - Biol. Plantarum 44: 471-473, 2001.

Farquhar G.D. Sharkey T.D.: Stomatal conductance and photosynthesis. - Annu. Rev. Plant Physio. 33: 317-345, 1982.

Gajić G., Mitrović M., Pavlović P. et al.: An assessment of the tolerance of Ligustrum ovalifolium Hassk. to traffic-generated $\mathrm{Pb}$ using physiological and biochemical marker. - Ecotox. Environ. Safe. 72: 1090-1101, 2009.

Gupta D., Nicoloso F., Schetinger M. et al.: Antioxidant defense mechanism in hydroponically grown Zea mays seedlings under moderate lead stress. - J. Hazard. Mater. 172: 479-484, 2009.

He B., He J., He X. et al.: [Effects of lead on physiological characteristics of bayberry seedlings.] - RDA J. Agro-Environ. Sci. 28: 1263-1268, 2009. [In Chinese]

He X., Chen L., He B. et al.: [Effect of lead nitrate on the growth of Myrica rubra.] - J. Fruit Sci. 21: 29-32, 2004. [In Chinese] 
Hussain M., Ahmad M.S.A., Kausar A.: Effect of lead and chromium on growth, photosynthetic pigments and yield components in mash bean [Vigna mungo (L.) Hepper]. - Pak. J. Bot. 38: 1389-1396, 2006.

Jamil M., Rehman S., Lee K.J. et al.: Salinity reduced growth PS2 photochemistry and chlorophyll content in radish. - Sci. Agr. 64: 111-118, 2007.

Karukstis K.: Chlorophyll fluorescence as a physiological probe of the photosynthetic apparatus. - In: Sheer H. (ed.): Chlorophylls. Pp. 769-795. CRC Press, Boca Raton 1991.

Ke S.: Effects of copper on the photosynthesis and oxidative metabolism of Amaranthus tricolor seedlings. - Agr. Sci. China. 6: 1182-1192, 2007.

Koyro H., Hussain T., Huchzermeyer B. et al.: Photosynthetic and growth response of a perennial halophytic grass Panicum turgidum to increasing $\mathrm{NaCl}$ concentrations. - Environ. Exp. Bot. 91: 22-29, 2013.

Li X., Bu N., Li Y. et al.: Growth, photosynthesis and antioxidant response of endophyte infected and non-infected rice under lead stress conditions. - J. Hazard Mater. 213-214: 55-56, 2012.

Meneguelli-Souza A.C., Vitória A.P., Vieira T.O. et al.: Ecophysiological responses of Eichhornia crassipes (Mart.) Solms to $\mathrm{As}^{5+}$ under different stress conditions. - Photosynthetica 54: 243-250, 2016.

Mils R.F., Krjiger G.C., Baccarini P.J. et al.: Functional expression of AtHMA4, a P-1B-type ATPase of the $\mathrm{Zn} / \mathrm{Co} / \mathrm{Cd} / \mathrm{Pb}$ subclass. - Plant J. 35: 164-176, 2003.

MLRC, MEPC: [Bulletin on national survey of soil contamination.] Reference No. 000014672/2014-00351. Ministry of envrironmental protection of China, Beijing 2014. [In Chinese]

Moustakas M., Lanaras T., Symeonidis L. et al.: Growth and some photosynthetic characteristics of field grown Avena sativa under copper and lead stress. - Photosynthetica 30: 389396, 1994.

Parys E., Romanowska E., Siedlecka M. et al.: The effect of lead on photosynthesis and respiration in detached leaves and in mesophyll protoplasts of Pisum sativum. - Acta Physiol. Plant. 20: 313-322, 1998.

Prasad M.N.V.: Metal-biomolecule complex in plants: Occurrence, function and applications. - Analysis 26: 25-27, 1998.

Rascio N., Navari-Izzo F.: Heavy metal hyperaccumulating plants: How and why do they do it? And what makes them so interesting? - Plant Sci. 180: 169-181, 2011.

Rashid A., Camm E.L., Ekramoddoullah A.K.: Molecular mechanism of action of $\mathrm{Pb}^{2+}$ and $\mathrm{Zn}^{2+}$ on water oxidizing complex of photosystem II. - FEBS Lett. 350: 296-298, 1994.

Sengar R.S., Gautam M., Sengar R.S. et al.: Lead stress effects on physiobiochemical activities of higher plants. - Rev.
Environ. Contam. T. 196: 73-93, 2008.

Shahid M., Pinelli E., Pourrut B. et al.: Lead-induced genotoxicity to Vicia faba L. roots in relation with metal cell uptake and initial speciation. - Ecotox. Environ. Safe. 74: 78-84, 2011.

Shakoor M.B., Ali S., Hameed A. et al.: Citric acid improves lead $(\mathrm{Pb})$ phytoextraction in Brassica napus $\mathrm{L}$. by mitigating $\mathrm{Pb}-$ induced morphological and biochemical damages. - Ecotox. Environ. Safe. 109: 38-47, 2014.

Sharma P., Dubey R.S.: Lead toxicity in plants. - Braz. J. Plant Physiol. 17: 35-52, 2005.

Skórzyńska-Polit E., Baszyński T.: Differences in sensitivity of the photosynthetic apparatus in Cd-stressed runner bean plants in relation to their age. - Plant Sci. 128: 11-21, 1997.

Stefanov K., Seizova K., Popova I. et al.: Effect of lead ions on the phospholipid composition in leaves of Zea mays and Phaseolus vulgaris. - J. Plant Physiol. 147: 243-246, 1995.

Subrahmanyam D., Rathore V.S.: Influence of manganese toxicity on photosynthesis in ricebean (Vigna umbellate) seedlings. - Photosynthetica 38: 449-453, 2000.

Tanyolaç D., Ekmekçi Y., Ünalan Ş.: Changes in photochemical and antioxidant enzyme activities in maize (Zea mays L.) leaves exposed to excess copper. - Chemosphere 67: 89-98, 2007.

Tzvetkova N., Miladinova K., Ivanova K. et al.: Possibility for using of two Paulownia lines as a tool for remediation of heavy metal contamination soil. - J. Environ. Biol. SN: 145-151, 2015.

van Assche F., Clijsters H.: Effects of metals on enzyme activity in plants. - Plant Cell Environ. 13: 195-206, 1990.

Watanabe M.E.: Phytoremediation on the brink of commercialization. - Environ. Sci. Technol. 31: 182-186, 1997.

Witters N., van Slycken S.V., Ruttens A. et al.: Short-rotation coppice of willow for phytoremediation of a metalcontaminated agricultural area: a sustainability assessment. Bioenerg. Res. 2: 144-152, 2009.

Wu X., Hong F.S., Liu C. et al.: Effects of $\mathrm{Pb}^{2+}$ on energy distribution and photochemical activity of spinach chloroplast. - Spectrochim. Acta A 69: 738-742, 2008a.

Wu X., Liu C., Qu C. et al.: Effects of lead on activities of photochemical reaction and key enzymes of carbon assimilation in spinach chloroplast. - Biol. Trace Elem. Res. 126: 269-279, 2008b.

Yadav S.K.: Heavy metals toxicity in plants: An overview on the role of glutathione and phytochelatins in heavy metal stress tolerance of plants. - S. Afr. J. Bot. 76: 167-179, 2010.

$\mathrm{Zu}$ Y., Li Y., Schvartz C. et al.: Accumulation of $\mathrm{Pb}, \mathrm{Cd}, \mathrm{Cu}$ and $\mathrm{Zn}$ in plants and hyperaccumulator choice in Lanping lead-zinc mine area, China. - Environ. Int. 30: 567-576, 2004. 